\title{
Analysis of Sites of Autolysis in Bacillus subtilis by Electron Microscopy
}

\author{
By I. D. J. BURDETT \\ Division of Microbiology, National Institute for Medical Research, London NW7 1 AA
}

(Received 24 January 1980; revised 28 March 1980)

Cell lysis in Bacillus subtilis 168/s trp thy and in an autolytic-deficient mutant, B. subtilis FJ6, was studied by following the release of wall material liberated by the two known autolysins, an $N$-acetylmuramoyl-L-alanine amidase and an endo- $\beta$ - $N$-acetylglucosaminidase. Lysing organisms were examined in thin sections by electron microscopy and measurements were made both of the location and size of holes produced by autolysin action and of peripheral wall thickness. In strain 168/s the initial site of lysis involved solubilization of the cross-wall and of one or both poles distal to the division site. Subsequently, the cylindrical wall was degraded through perforations at an increasing number of sites. Specific sites of autolysis, at the cross-wall and at one pole, were also observed in organisms prefixed with formaldehyde in a buffer of low ionic strength, although these effects were not observed in strain FJ6. In strain 168/s the bulk of the autolysin appeared to be located at the cross-wall and at one distal pole. The peripheral wall was reduced in thickness in autolysing cells, although it was uncertain whether the reduction was due to autolytic attack at the outer surface, to contraction of the wall in the suspending buffer or to shrinkage during preparation for electron microscopy. Lysis of strain FJ6 involved the initial breakdown of the cytoplasmic membrane and leakage of cellular contents through a limited number of sites along the wall. In contrast, lysis in $B$. subtilis MB21, the parental strain of FJ6, was similar to that described for strain $168 / \mathrm{s}$.

\section{INTRODUCTION}

Many bacteria possess lytic enzymes (autolysins) which are capable of hydrolysing the peptidoglycan component of their walls (for a recent review, see Rogers, 1979). The functional role of these enzymes is unknown, but processes in which autolysins may be involved include the following: (i) separation of daughter cells at division (Tomasz, 1968; Fan, 1970; Forsberg \& Rogers, 1974; Chatterjee et al., 1976; Fein \& Rogers, 1976); (ii) biosynthesis, remodelling and turnover of the wall related to expansion during growth (Rogers, 1970; Daneo-Moore \& Shockman, 1977); (iii) the killing action of antibiotics interfering with wall biosynthesis (Rogers, 1967; Rogers \& Forsberg, 1971); (iv) peptidoglycan hydrolysis associated with penetration of the flagellum basal organelle through the cell wall (Fein \& Rogers, 1976; Fein, 1979).

These roles all suggest that autolysin action is probably very localized and rigorously controlled, although little is known either of the cellular location of the enzymes involved or of the manner in which autolysin activity is regulated. One direct approach to locate the sites of autolysin action is to examine by electron microscopy the course of lysis of intact cells suspended in buffers of suitable $\mathrm{pH}$ and ionic strength. Using this approach, the initial and very specific site of autolytic attack in Streptococcus faecalis has been shown to involve the leading edge of the cross-wall (Higgins et al., 1970). When walls of $S$. faecalis 
were exposed to lysozyme or to partially purified autolysin, random dissolution of the wall was observed, suggesting that the proposed sequence of autolytic degradation at the cross-wall may actually reflect the location of the sole known autolysin, a muramidase (Shockman \& Martin, 1968). The location of the autolysin at the cross-wall would be consistent with the known pattern of surface enlargement, because new wall is produced by the peeling apart of the cross-wall to form two daughter cocci (Higgins \& Shockman, 1976).

In Bacillus subtilis two autolysins are known to be present: an $N$-acetylmuramoyl-Lalanine amidase, which is the principal autolysin, and an endo- $\beta$ - $N$-acetylglucosaminidase (Young, 1966; Hughes, 1970; Brown \& Young, 1970; Fan \& Beckman, 1972). The amidase cleaves the L-alanine residue linked to $N$-acetylmuramic acid whilst the glucosaminidase releases fragments with $N$-acetylglucosamine at the reducing end of glycan chains. The two autolysins differ in their $\mathrm{pH}$ optima, the amidase being operative over a broad range (pH 6.5 to 9.5) with an optimum of about 8.0 (Herbold \& Glaser, 1975), whereas the glucosaminidase exhibits optimal activity at pH 5.0 to 6.0 (Brown \& Young, 1970; Herbold \& Glaser, 1975). It is therefore possible, at least in principle, to follow the course of lysis of organisms incubated at the appropriate $\mathrm{pH}$ in order to examine any visible differences in either the presumed sites of autolytic attack or the sequence of wall degradation. These objectives form the subject of the present study.

\section{METHODS}

Bacterial strains and media. Bacillus subtilis 168/s trp thy (Sargent, 1973), B. subtilis MB21 leu met (Piggot \& Taylor, 1977) and B. subtilis FJ6, an autolysin-deficient mutant derived from MB21 (Fein \& Rogers, 1976), were grown at $35^{\circ} \mathrm{C}$ in a shaking water bath in a minimal salts medium (MS: Sargent, 1973; Burdett \& Higgins, 1978), with glucose as carbon source, or in L-broth (LB: see Miller, 1972). L-broth contained (per litre) $10 \mathrm{~g}$ tryptone (Difco), $5 \mathrm{~g}$ yeast extract (Difco) and $10 \mathrm{~g} \mathrm{NaCl}$. Cultures were maintained at an $A_{\text {gi5 }}$ of less than 0.4 by periodic dilution with prewarmed medium.

Procedure for cell lysis. Cultures $(100 \mathrm{ml}$ per $500 \mathrm{ml}$ flask) were harvested by centrifugation at $5000 \mathrm{rev}$. $\min ^{-1}$ for $5 \mathrm{~min}$ at $4^{\circ} \mathrm{C}$ in a Sorvall RC2-B centrifuge and washed once in TK buffer (0.05 to 0.1 M-Tris/ $\mathrm{HCl}$, pH 8.6, containing 0.05 to $0.1 \mathrm{M}-\mathrm{KCl}$; Fan \& Beckman, 1972) or TM buffer (0.05 M-Tris/maleic anhydride, pH 5.5; Fan \& Beckman, 1972) before resuspension to an $A_{675}$ of 0.5 to 0.6 in fresh buffer. Samples (about $10 \mathrm{ml}$ ) were placed in optically matched tubes $(12 \times 155 \mathrm{~mm}$ ) filled to within a few $\mathrm{mm}$ of the top, capped with a plastic stopper and sealed with Parafilm. All samples, including a blank containing only the buffer, were incubated in a water bath maintained at $35^{\circ} \mathrm{C}$. The decrease in $A_{675}$ was followed using a Pye Unicam SP600 spectrophotometer.

Electron microscopy. (i) Samples $(2$ to $5 \mathrm{ml}$ ) were fixed with formaldehyde/glutaraldehyde (Burdett \& Higgins, 1978), postfixed with $1 \%(\mathrm{w} / \mathrm{v}) \mathrm{OsO}_{4}$ and further processed as described previously (Burdett \& Higgins, 1978; Burdett, 1979) except that samples were embedded in a low-viscosity resin (Spurr, 1968). (ii) Some samples were also prefixed with $0.1 \mathrm{vol} .1 .5 \%(\mathrm{v} / \mathrm{v})$ formaldehyde in sodium cacodylate buffer $(0.025$ to $0.175 \mathrm{M}, \mathrm{pH} 6.0$ to 7.2$)$, centrifuged at room temperature after 2 to $5 \mathrm{~min}$ and resuspended in $2 \mathrm{ml}$ of full-strength fixative for $2 \mathrm{~h}$ at room temperature. Formaldehyde fixative was prepared by warming paraformaldehyde (TAAB Laboratories, Reading) to $60^{\circ} \mathrm{C}$, adding a few drops of $1 \mathrm{M}-\mathrm{NaOH}$, and filtering the solution (Glauert, 1975). Samples were washed by centrifugation in $0.05 \mathrm{M}$-sodium cacodylate buffer, $\mathrm{pH} 6.2$, containing $0.08 \mathrm{M}-\mathrm{KCl}$ and $0.01 \mathrm{M}$-magnesium acetate, enrobed in $2 \%(\mathrm{w} / \mathrm{v})$ agar, cut into small pellets (about $1 \mathrm{~mm}^{3}$ ) and washed overnight in buffer (Burdett \& Higgins, 1978). Subsequent processing was as described in (i), above.

Sections were cut with glass or diamond knives, picked up on copper grids bearing a collodion/carbon support film and stained with uranyl acetate and lead citrate. Micrographs were taken on a Philips EM300 at $60 \mathrm{kV}$ using a $50 \mu \mathrm{m}$ objective aperture and a liquid nitrogen anti-contamination trap.

For purposes of measurement, only longitudinally sectioned cells were photographed. Mcasurements of cell length were obtained from photographic prints enlarged to 50000 to $100000 \times$; all other measurements, such as wall thickness, were determined from micrographs using an eye-piece ruled in $0.1 \mathrm{~mm}$ divisions or dirertly from the photographic negative using a dissecting microscope fitted with a similar graticule. Magnification of the EM300 was calibrated with the replica of a diffraction grating (2160 lines $\left.\mathrm{mm}^{-1}\right)$. 


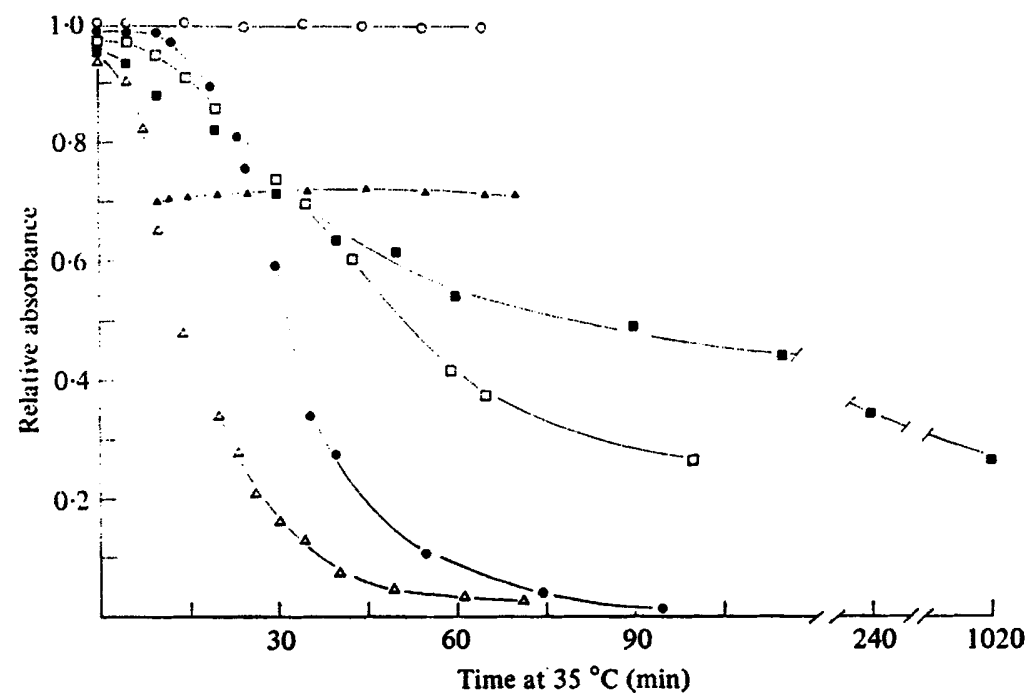

Fig. 1. Lysis of B. subtilis 168/s (grown in MS medium) and FJ6 (grown in LB medium). Strain $168 / \mathrm{s}$ prefixed with formaldehyde/glutaraldehyde before suspension in $0.1 \mathrm{M}$-TK buffer, $\mathrm{pH}$ $8.6(C)$ or prefixed after a decrease of $30 \%$ in $A_{675}(\Delta)$; strain $168 / \mathrm{s}$ in $0.05 \mathrm{M}-\mathrm{TK}$ buffer, $\mathrm{pH}$ $8.6(O)$, in 0.1 M-TK buffer, pH 8.6 $(\triangle)$ or in 0.05 M-TM buffer, pH 5.5 ( $\square$ ); strain FJ6 in 0.1 M-TK buffer, pH 8.6 (ם).

\section{RESULTS}

Cell lysis at $35^{\circ} \mathrm{C}$

Samples of $B$. subtilis $168 / \mathrm{s}$ incubated in $0 \cdot 1 \mathrm{M}$-TK buffer, $\mathrm{pH} 8 \cdot 6$, containing $0 \cdot 1 \mathrm{M}-\mathrm{KCl}$, underwent rapid lysis; more than $85 \%$ of the decrease in $A_{675}$ occurred within 20 min (Fig. 1). The rate of lysis was lower for samples incubated in $0.05 \mathrm{M}$-TK buffer or in 0.05 M-TM buffer, $\mathrm{pH} 5 \cdot 5$. Addition of $0.1 \mathrm{vol}$. formaldehyde/glutaraldehyde fixative to samples undergoing lysis in $0.1 \mathrm{M}-\mathrm{TK}$ buffer, $\mathrm{pH} 8.6$, halted autolysis immediately; no detectable decrease in $A_{675}$ was observed in samples fixed prior to incubation at $35^{\circ} \mathrm{C}$ (Fig. 1).

Bacillus subtilis FJ6 suspended in 0.1 M-TK buffer, pH 8.6 , lysed at only $12 \%$ of the rate observed in $B$. subtilis $168 / \mathrm{s}$ (Fig. 1).

\section{Electron microscopy of cell lysis in B. subtilis $168 / \mathrm{s}$}

(i) $T K$ buffer, $p H 8 \cdot 6$. The appearance of the wall in sectioned cells of strain $168 / \mathrm{s}$ taken from exponentially growing cultures (MS+glucose; doubling time, $60 \mathrm{~min}$ ) is shown in Fig. 2(a). Characteristically the wall appeared as a tribanded structure (dark-light-dark) in axial sections. The thickness of the peripheral wall along the cylindrical portion of the cell was $26.9 \pm 3.8 \mathrm{~nm}$ [mean \pm one standard deviation; number of observations $(n)=42$ ], without any obvious discontinuity of structure. In dividing organisms, septal wall can be distinguished from peripheral wall by the presence of raised tears produced by an initial split at the base of the cross-wall (Fig. $2 a$ ). These tears are bilaterally displaced during pole enlargement (Burdett \& Higgins, 1978; Burdett, 1979). Previous studies have shown that the proportion of wall formed by separation of the cross-wall into two nascent poles amounts to about $15 \%$ of the total surface area or wall volume in rods (Burdett \& Higgins, 1978; Burdett, 1979). A detailed analysis of cross-wall assembly and pole formation in strain 168/s has been described previously (Burdett \& Higgins, 1978). The poles distal to the division site were frequently of different shapes, one being more rounded in profile that the other (Fig. 2a). 

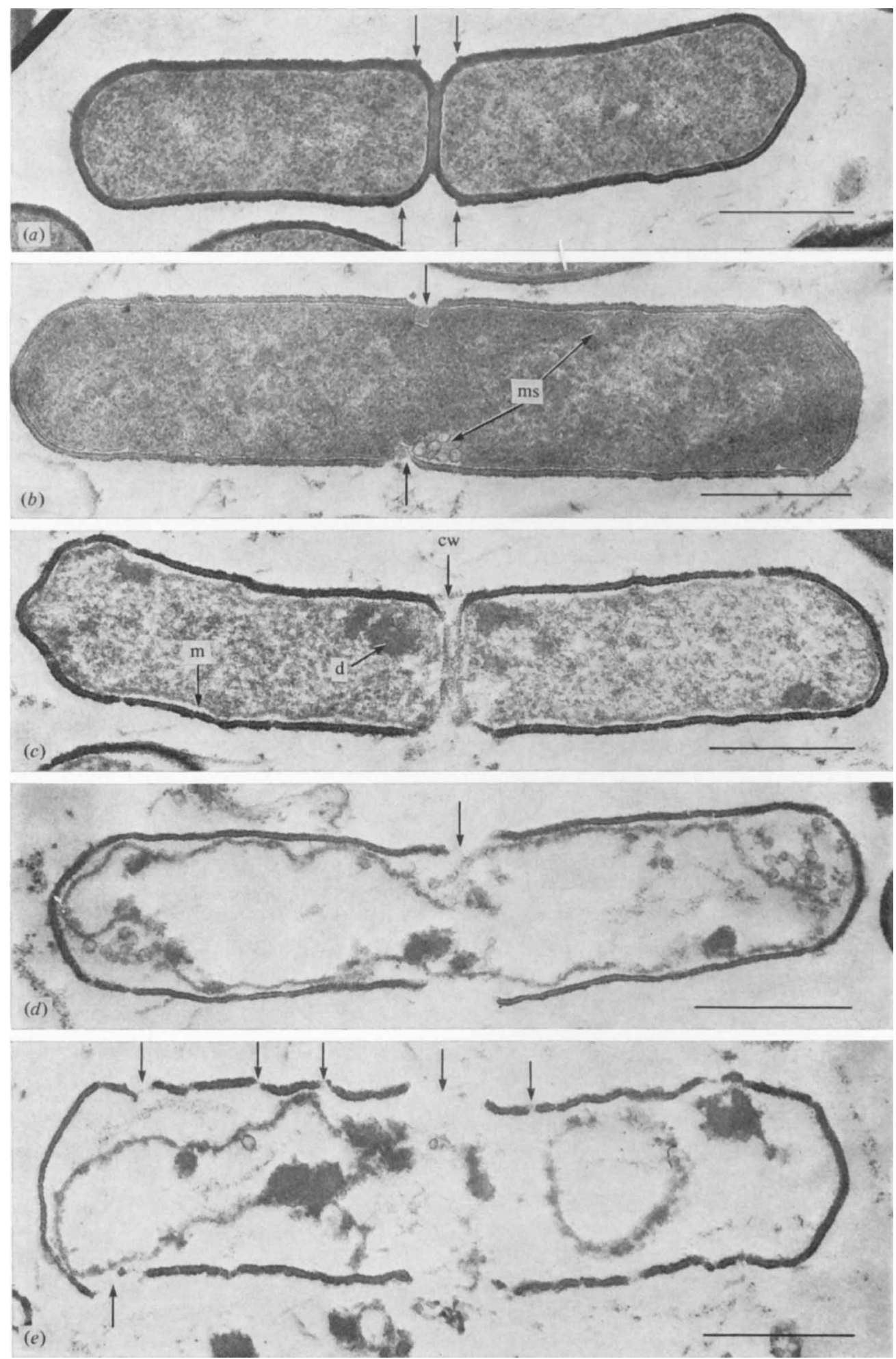

Fig. 2. For legend see opposite. 

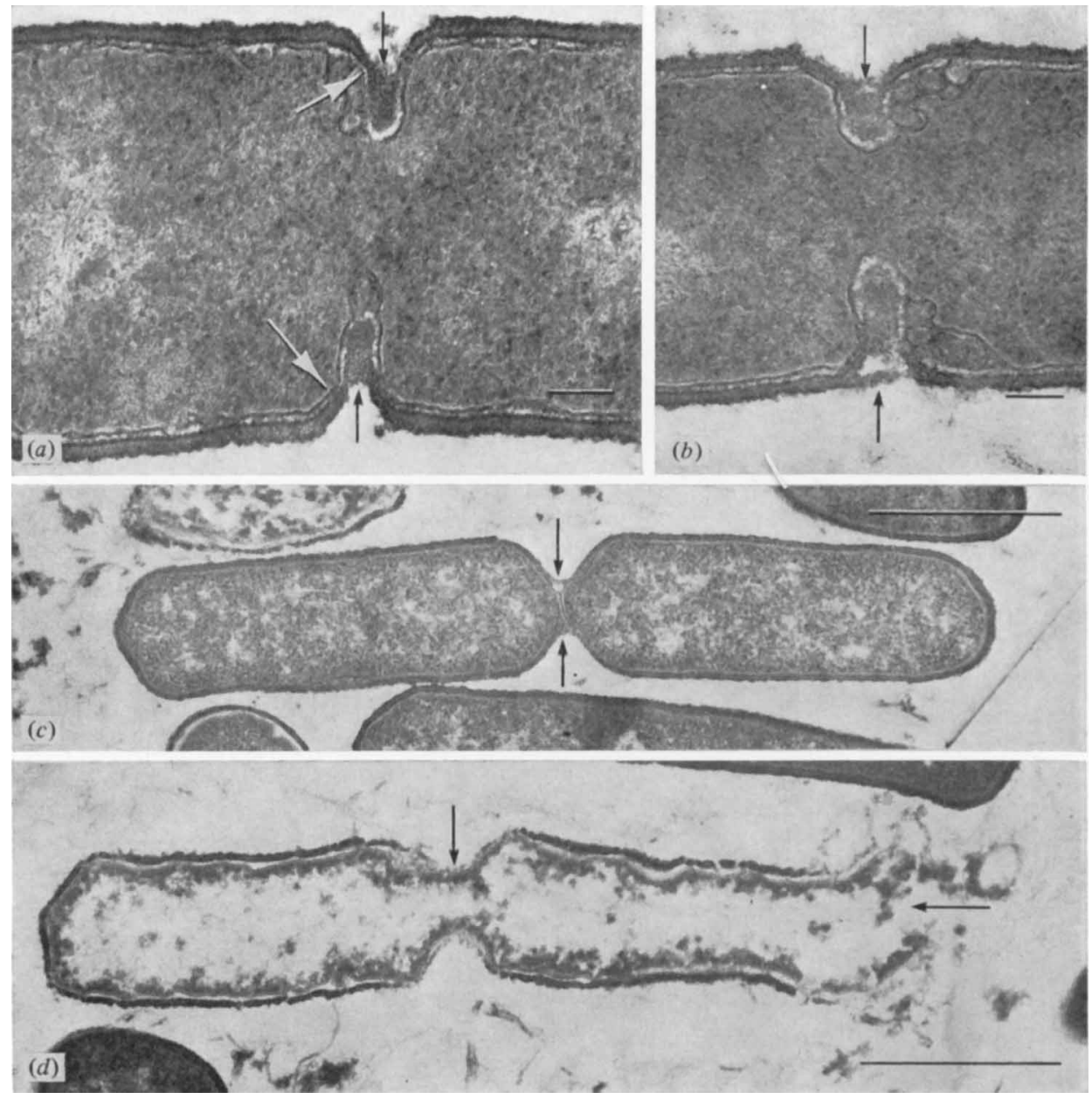

Fig. 3. Longitudinal sections of $B$. subtilis $168 / \mathrm{s}$ after incubation in $0 \cdot 1 \mathrm{M}-\mathrm{TK}$ buffer, pH 8.6 , for $0 \mathrm{~min}(a, b)$ or in $0.05 \mathrm{M}-\mathrm{TM}$ buffer, pH 5.5, for $0 \mathrm{~min}(c)$ and $30 \mathrm{~min}(d)$. Black arrows in $a$ and $b$ show the base of the cross-wall; white arrows indicate the junction with the polar wall, reduced in thickness. Arrows in $c$ and $d$ show the division site as a shallow groove $(c, d)$ and one lysed distal pole $(d)$. Bar markers represent $0.1 \mu \mathrm{m}(a, b)$ or $0.5 \mu \mathrm{m}(c, d)$.

When cells of strain 168/s were suspended in 0.1 M-TK buffer, $\mathrm{pH} 8 \cdot 6$, the organisms appeared plasmolysed, showing retraction of the outer edge of the cytoplasmic membrane away from the inner edge of the wall and the extrusion of mesosomes as separate vesicles (Fig. $2 b$ ). Dense granules were observed in the majority of lysing organisms (Fig. 2c). Even in the sample taken immediately after resuspension of the organisms in TK buffer, many cells containing a partially built or completed cross-wall showed evidence of septal degradation. Invariably the point of autolytic attack was the base of the cross-wall or there was more extensive damage to the cross-wall plus the nascent poles (Figs 2 and $3 a, b$ ). Measurements of the average width of the cross-wall in cells after 3 min incubation indicated

Fig. 2. L.ongitudinal sections of $B$. subtilis $168 / \mathrm{s}$ from exponentially growing cultures in MS medium (a) and immediately after suspension in $0.1 \mathrm{M}$-TK buffer, pH $8.6(\mathrm{~b})$, and after $5 \mathrm{~min}(\mathrm{c})$ and $18 \mathrm{~min}$ $(d, e)$. Arrows in a show location of surface markers delimiting septal from peripheral wall; note the difference in shape of each distal pole. Arrows in $d$ and $e$ show gaps in the wall. $\mathrm{m}$, Cytoplasmic membrane; ms, mesosome; d, dense granules; cw, cross-wall. Bar markers represent $0.5 \mu \mathrm{m}$. 


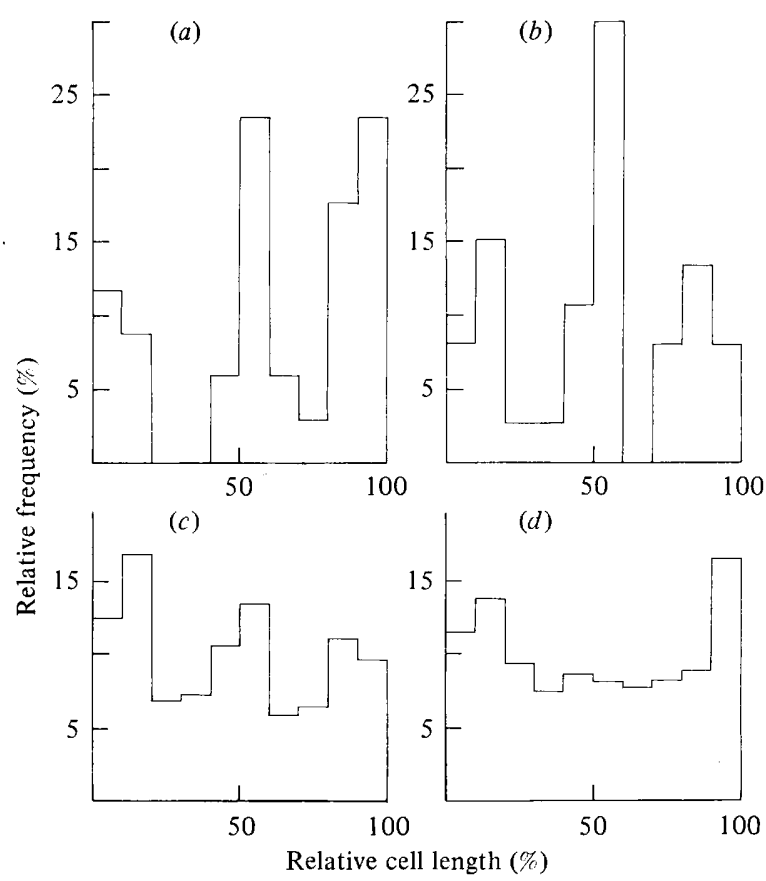

Fig. 4. Histogram of location of sites of lysis in $B$. subtilis $168 / \mathrm{s}$ after incubation in $0 \cdot 1 \mathrm{M}$-TK buffer, $\mathrm{pH} 8 \cdot 6$, for $0 \mathrm{~min}$ ( $a$; number of holes, $n=34), 5 \min (b, n=37), 12 \mathrm{~min}(c, n=208)$ and $18 \mathrm{~min}(d, n=583)$; total no. of longitudinal sections, 117 . The location of each site is expressed as a percentage of the cell length.

that the width $(55 \cdot 61 \pm 19 \cdot 46 \mathrm{~nm} ; n=149)$ was greater than the mean value in the control sample $(39.20 \pm 8.98 \mathrm{~nm} ; n=130)$. In contrast, the thickness of the peripheral wall $(23.9 \pm 5.9 \mathrm{~nm} ; n=40)$ was decreased in comparison with the control; throughout subsequent stages of autolysis the peripheral wall thickness remained fairly constant, varying from $22 \cdot 8 \pm 2 \cdot 8 \mathrm{~nm}(n=76)$ to $24 \cdot 3 \pm 3 \cdot 1 \mathrm{~nm}(n=42)$. These values were based on 158 measurements taken at the following incubation times: $0 \mathrm{~min}, 5 \mathrm{~min}, 12 \mathrm{~min}, 18 \mathrm{~min}$.

The course of lysis was also examined in samples incubated in $0.05 \mathrm{M}-\mathrm{TK}$ buffer, $\mathrm{pH} 8 \cdot 6$. These showed essentially the same characteristics as those reported above although plasmolysis was less evident and mesosomes consisted of tubulo-vesicular structures or sheets of membrane rather than extruded vesicles.

Further analysis of the course of lysis in strain $168 / \mathrm{s}$ was based on samples incubated in $0 \cdot 1 \mathrm{M}$-TK buffer, $\mathrm{pH} 8 \cdot 6$. Although the most obvious site of autolytic attack appeared to involve the cross-wall, additional sites of wall dissolution were noted along the cylindrical portion of the cell in all samples taken during autolysis (Fig. $2 c, d, e$ ). To facilitate comparison of the sites of lysis, measurements were made both of the location of gaps along the wall and the size of the holes presumed to be caused by autolytic attack. Because single longitudinal sections were used, the number and location of visible gaps in the wall were certainly an underestimate of the likely total.

The location of gaps, visible as discontinuities of the essentially tribanded wall, were expressed as a percentage of the cell length ( 0 to $100 \%$ from one pole to the other); the range of cell lengths was 1.34 to $3.89 \mu \mathrm{m}$. For the zero time and 5 min samples, a conspicuous peak was observed at the site of the cross-wall (i.e. $50 \%$ cell length); additional but smaller peaks were present at 0 to $20 \%$ and 70 to $100 \%$, close to each pole distal to the division site (Fig. $4 a, b$ ). In subsequent samples, the gaps became apparent along the entire length of the cells (Fig. $4 c, d$ ). 

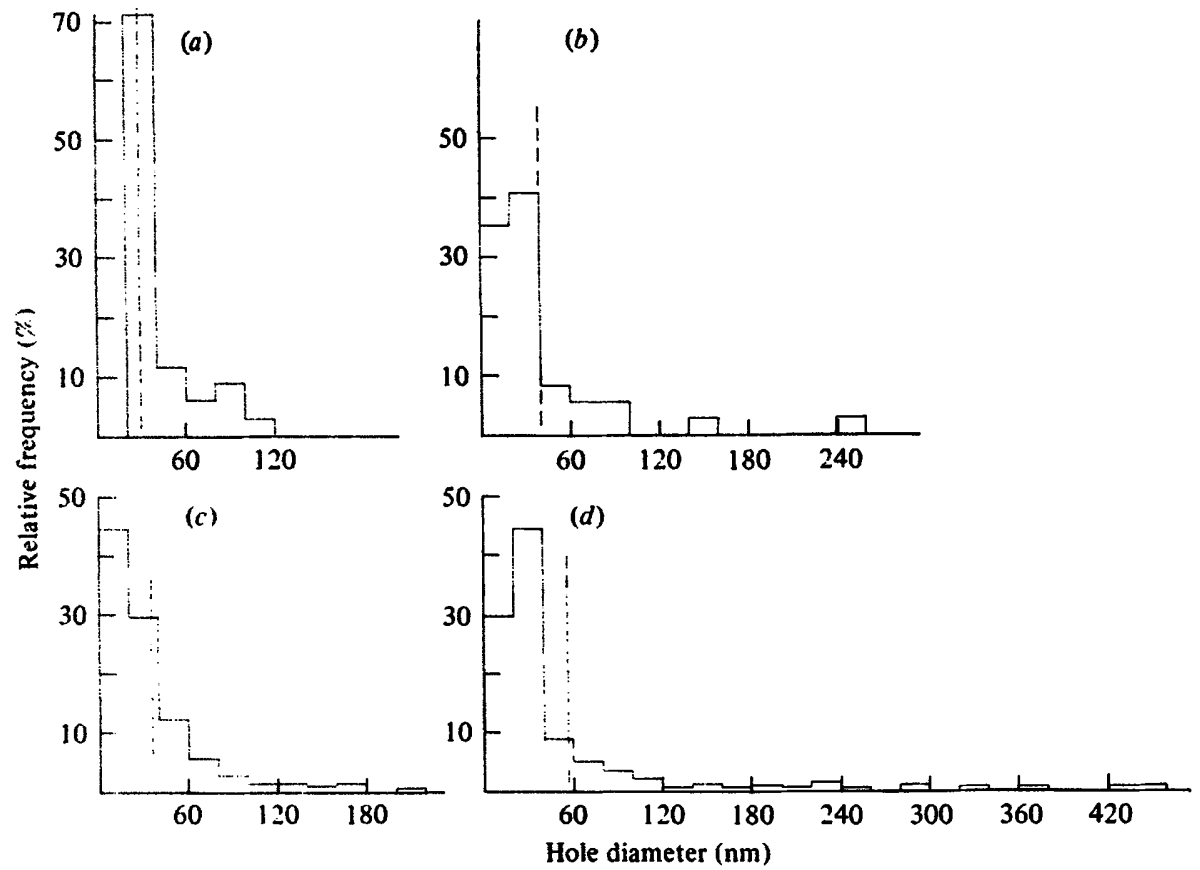

Fig. 5. Histogram showing width of holes in walls of $B$. subtilis $168 / \mathrm{s}$ after autolysis in $0.1 \mathrm{M}$-TK buffer, pH 8.6 (see also Fig. 4) for $0 \min (a, n=34), 5 \min (b, n=37), 12 \min (c, n=208)$ and $18 \mathrm{~min}(d, n=583)$. Dashed lines indicate mean values: $29.71 \mathrm{~nm}(a), 39.34 \mathrm{~nm}(b), 36 \cdot 13 \mathrm{~nm}$ (c), $46 \cdot 12 \mathrm{~nm}(d)$

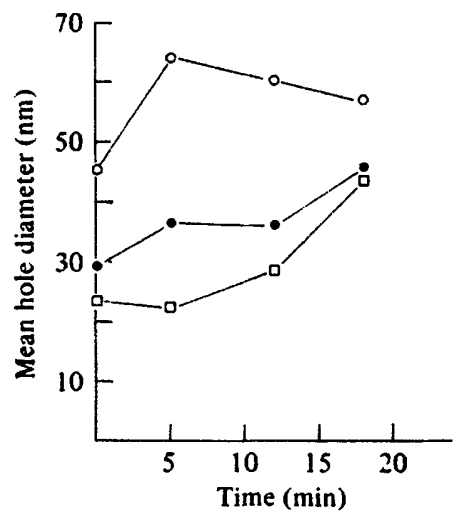

Fig. 6. Plot of mean hole diameter against time of incubation of $B$. subtilis $168 / \mathrm{s}$ in $0.1 \mathrm{M}-\mathrm{TK}$ buffer, pH 8.6, showing results for holes at the cross-wall or centre of the cell $(O)$, along the peripheral wall ( $:$ ) , or at the septal plus peripheral walls $(O)$.

The maximum width of the holes increased from a mean value of $29 \cdot 71 \pm 22 \cdot 0 \mathrm{~nm}$ to $46 \cdot 12 \pm 58 \cdot 16 \mathrm{~nm}$ during the 0 to $18 \mathrm{~min}$ period (Fig. 5); the large standard deviations indicate the extent of the variation observed. The measurements were based on a total of 862 holes per 117 longitudinally sectioned cells. When gaps at the cross-wall, or centre of the cell, were distinguished from those along the peripheral wall, the results suggested that the size of the gaps produced by septal dissolution initially increased rapidly and then remained relatively constant. The average width of gaps along the cylindrical wall apparently increased after solubilization of the cross-wall (Fig. 6). Thus, the rate of lysis at septal locations appeared to decrease after about $5 \mathrm{~min}$ incubation in TK buffer. In contrast, 

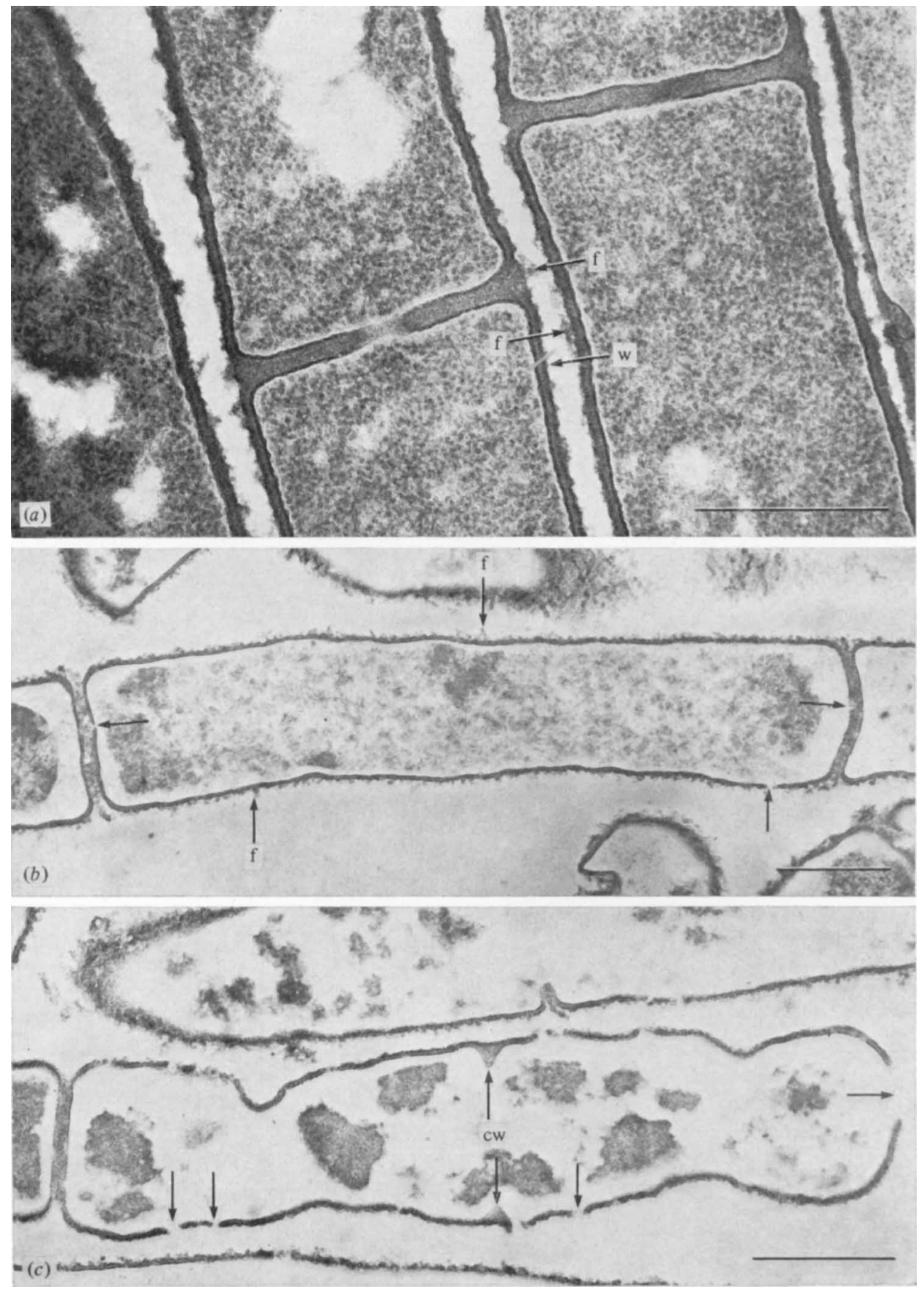

Fig. 7. Longitudinal sections of $B$. subtilis FJ6 from exponentially growing cultures in LB medium (a) and during incubation in $0.1 \mathrm{M}$-TK buffer, pH 8.6, for $1 \mathrm{~h}(b)$ and $3 \mathrm{~h}(c)$. The outer surface of the organism is covered with a fringe ( $f$ ) associated with the wall (w). Sites of wall damage are shown by arrows in $b$ and $c$; cw, cross-wall. Note the absence of cytoplasmic membrane profiles in $b$ and $c$. Bar markers represent $0.5 \mu \mathrm{m}$. 
the rate of lysis at the peripheral wall increased, due perhaps to the continuing enlargement of gaps along the wall. A small proportion of the cells also appeared to be resistant to autolysis.

(ii) $T M$ buffer, $p H$ 5.5. Although the cross-wall also appeared to be the primary site of autolytic attack in strain 168/s incubated in 0.05 M-TM buffer, pH 5.5, differences were noted in the pattern of lysis. The most conspicuous difference was an apparent partial separation of the cross-wall into two halves (Fig. $3 c$ ) resulting in a shallow groove reminiscent of the 'constrictive' divisions seen in Escherichia coli (Burdett \& Murray, 1974). In B. subtilis 168/s grown in MS+glucose, separation of the cross-wall precedes septal closure (Burdett \& Higgins, 1978). During subsequent stages of lysis the peripheral wall and one or both distal poles were extensively degraded (Fig. $3 d$ ). The loss of cell shape rendered measurements of the distribution of gaps along the wall of doubtful value. The peripheral wall thickness $(24 \cdot 1 \pm 3.91 \mathrm{~nm} ; n=75)$ was slightly less than that of the control sample.

\section{Electron microscopy of lysis in B. subtilis FJ6}

In organisms from exponentially growing cultures in LB medium (doubling time, $30 \mathrm{~min}$ ) long chains of unseparated cells were present. In thin section the peripheral wall, unlike that of strain $168 / \mathrm{s}$, bore a fringe of material along the exterior face which could represent wall material not lost by turnover (Fig. $7 a$ ). The rate of peptidoglycan turnover in strain FJ6 is much lower than in other strains (Fein \& Rogers, 1976). The total thickness of the wall (including the outer limits of the fringe) was $50 \cdot 90 \pm 7.60 \mathrm{~nm}(n=72)$.

The pattern of lysis in strain FJ6 incubated in $0 \cdot 1$ m-TK buffer, $\mathrm{pH} 8.6$, was more complex to analyse than that in strain $168 / \mathrm{s}$ because breakdown of the walls was not observed in samples taken after up to $3 \mathrm{~h}$ incubation at $35^{\circ} \mathrm{C}$. Instead, the initial stages of lysis appeared to involve the breakdown of the cytoplasmic membrane (Fig. $7 b$ ). Only at later stages of autolysis ( $>3 \mathrm{~h}$ ) were gaps seen in the peripheral wall. Thus, during the first $3 \mathrm{~h}$ of autolysis the preparations were largely composed of empty walls. Presumably a small number of gaps were, in fact, present although difficult to detect by sectioning. Partial dissolution of the cross-walls was also noted (Fig. $7 b, c$ ) although complete autojysis at this location did not occur. Only in samples left at $35^{\circ} \mathrm{C}$ for up to $17 \mathrm{~h}$ were wall fragments observed. The sequence of lysis in B. subtilis MB21, the parent strain of FJ6, when grown on LB medium and lysed in $0.1 \mathrm{M}-\mathrm{TK}$ buffer, $\mathrm{pH} 8.6$, closely resembled that described for strain 168/s. Degradation of the cytoplasmic membrane prior to dissolution of the wall has not been observed in strain MB21 (unpublished observations).

In comparison with the control sample, the total thickness of the wall, including the fringe, in lysing cells was slightly greater: $61.47 \pm 13.73 \mathrm{~nm}(n=68$; after $1 \mathrm{~h}$ incubation) and $56.98 \pm 13.54 \mathrm{~nm}(n=64$; after $3 \mathrm{~h}$ incubation). Separate measurements of the wall thickness, omitting the fringe, were also made: $36 \cdot 30 \pm 5.90 \mathrm{~nm}(n=72$; control sample); $26.59 \pm 4.89 \mathrm{~nm}\left(n=68 ; 1 \mathrm{~h}\right.$ at $\left.35^{\circ} \mathrm{C}\right) ; 23.43 \pm 6.19 \mathrm{~nm}\left(n=64 ; 3 \mathrm{~h}\right.$ at $\left.35^{\circ} \mathrm{C}\right)$. The average widths of the cross-wall for these three samples were, respectively, $75.5 \pm 10.6 \mathrm{~nm}(n=44)$, $87 \cdot 89 \pm 29 \cdot 15 \mathrm{~nm}(n=52)$ and $82 \cdot 39 \pm 19 \cdot 83 \mathrm{~nm}(n=49)$.

\section{Wall structure of formaldehyde-fixed cells}

When strain 168/s, grown in MS medium, was prefixed with formaldehyde in 0.025 to $0.05 \mathrm{M}$-cacodylate buffer, $\mathrm{pH} 6.2$, wall material appeared to be absent at specific sites. When these locations were plotted as a percentage of the relative cell length, the frequency distribution showed two major peaks (Fig. 8), one at the centre (i.e. $50 \%$ relative cell length) and the other at one distal pole; for convenience, organisms lysed at one distal pole were oriented to the right. The range of cell lengths was 1.71 to $5.08 \mu \mathrm{m}(n=48)$; the peripheral wall thickness was $23.9 \pm 3.2 \mathrm{~nm}(n=100)$. The cells lysed at one distal pole 


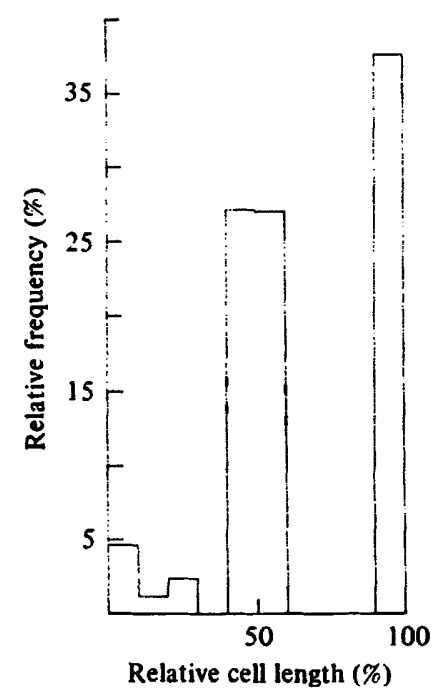

Fig. 8. Histogram showing locations of sites of wall damage $(n=86$ per 48 longitudinal cell profiles), expressed as a percentage of the cell length, in sections of $B$. subtilis $168 / \mathrm{s}$ prefixed with formaldehyde in $0.025 \mathrm{M}$-cacodylate buffer, $\mathrm{pH} 6.2$.

were mainly organisms which did not contain a cross-wall (Fig. $9 a$ ). In all other cases, the major site of wall dissolution involved the cross-wall and nascent poles (Fig. $9 b$ ). Even in organisms containing no visible indentation of the membrane at the division site, gaps in the wall were noted (Fig. 9c), presumably traversing the circumference of the cell. The wall adjacent to a site of lysis appeared thinner than the peripheral wall, perhaps increasing along a gradient of thickness (Fig. $9 a, b$ ).

With cacodylate buffer at $0.175 \mathrm{M}$, the apparent removal of wall material was less specific and extensive wall damage was observed. Similar observations were made over the $\mathrm{pH}$ range $5 \cdot 5$ to $7 \cdot 4$. In strain $168 / \mathrm{s}$ grown in LB medium, wall material was apparently degraded at the external face, resulting in partial (Fig. 10b) or complete (Fig. 10c) degradation of the cross-wall; a control sample is shown in Fig. $9(d)$. In many cases, one of the distal poles was also covered by a continuous layer of wall material (Fig. 10a).

Wall degradation was not observed in strain FJ6 grown in LB medium and prefixed with formaldehyde (in $0.175 \mathrm{M}$-cacodylate, $\mathrm{pH} 6.2$ ). The only obvious difference from the control sample was a separation of the cytoplasmic membrane from the wall (Fig. 10d) and a reduction in the thickness of the wall plus fringe from $50.9 \pm 7.6 \mathrm{~nm}$ in the control to $37 \cdot 2 \pm 6 \cdot 2 \mathrm{~nm}(n=74)$ in organisms fixed with formaldehyde.

\section{DISCUSSION}

The observations reported here suggest that most of the active autolysin is located at the cross-wall and that disruption of the peripheral wall in $B$. subtilis during lysis occurs only after septal dissolution has been initiated. Much of the visible evidence for autolysin action suggests that the process occurs at the exterior face of the wall or at the base of the cross-wall. The binding of the autolysins presumably depends on the high affinity of the enzymes for the wall (Herbold \& Glaser, 1975). Degradation of the wall appears to occur, not by a process of continuous thinning, but by an increase both in the size and number of gaps in the wall. The remaining portions of the wall therefore remain at a relatively constant thickness. That is, the wall is actually perforated at an increasing number of sites by holes which become larger in size. 

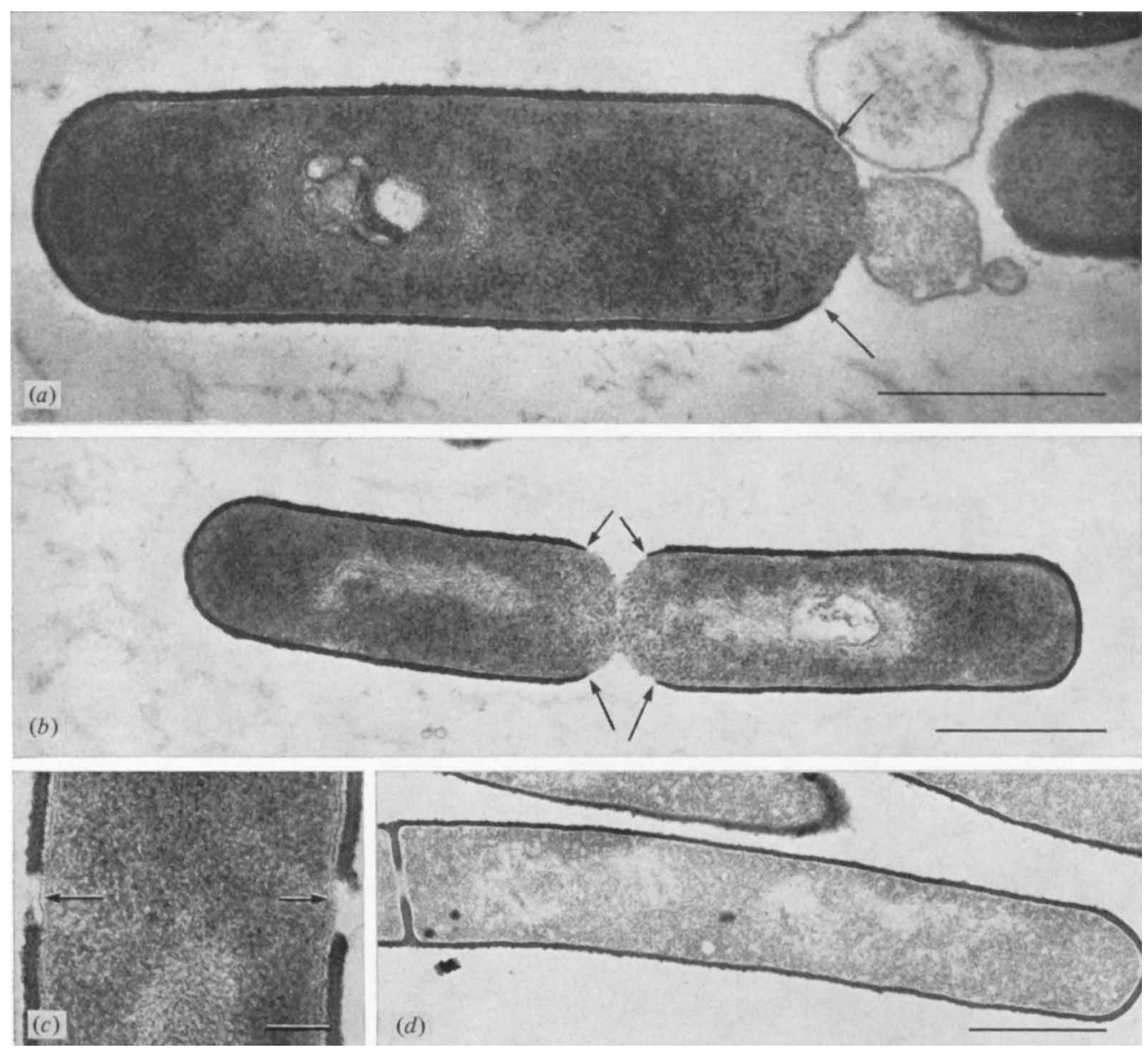

Fig. 9. $(a, b, c)$ Longitudinal sections of $B$. subtilis $168 / \mathrm{s}$ grown in MS medium prefixed with formaldehyde in $0.025 \mathrm{M}$-cacodylate buffer, pH 6.2. Arrows show wall degradation at one distal pole $(a)$, at the cross-wall $(b)$ or at the centre of the cell $(c)$. (d) Longitudinal section of $B$. subtilis $168 / \mathrm{s}$ grown in LB medium and fixed with formaldehyde/glutaraldehyde. Bar markers represent $0.5 \mu \mathrm{m}(a, b, d)$ or $0.1 \mu \mathrm{m}(c)$.

The extent to which the interpretation given above can be extrapolated to growing organisms is uncertain because the material on which the observations are based consisted of dense suspensions of cells incubated in buffers. These conditions may not necessarily reflect the distribution or activity of autolysins in dividing bacteria. However, the experiments of Westmacott \& Perkins (1979), involving the addition of lysozyme or exogenous autolysin to cultures of $B$. cereus, also suggest that the cross-wall may be a major site where autolysins are localized or that the septum is especially sensitive to autolytic degradation.

Autolysing cells of strain 168/s also showed a decrease in the thickness of the peripheral wall, which may be due to: (i) loss of wall material; (ii) changes in the electrostatic properties of wall constituents when the cells are suspended in buffers of altered $\mathrm{pH}$ and ionic strength (Marquis, 1968); (iii) shrinkage of the wall due to fixation, dehydration and embedding for electron microscopy. Beveridge \& Murray (1979) have shown that the dimensions of isolated walls of $B$. subtilis can be significantly altered by the nature of the fixative and duration of fixation. They also suggest that the minimum thickness of purified 

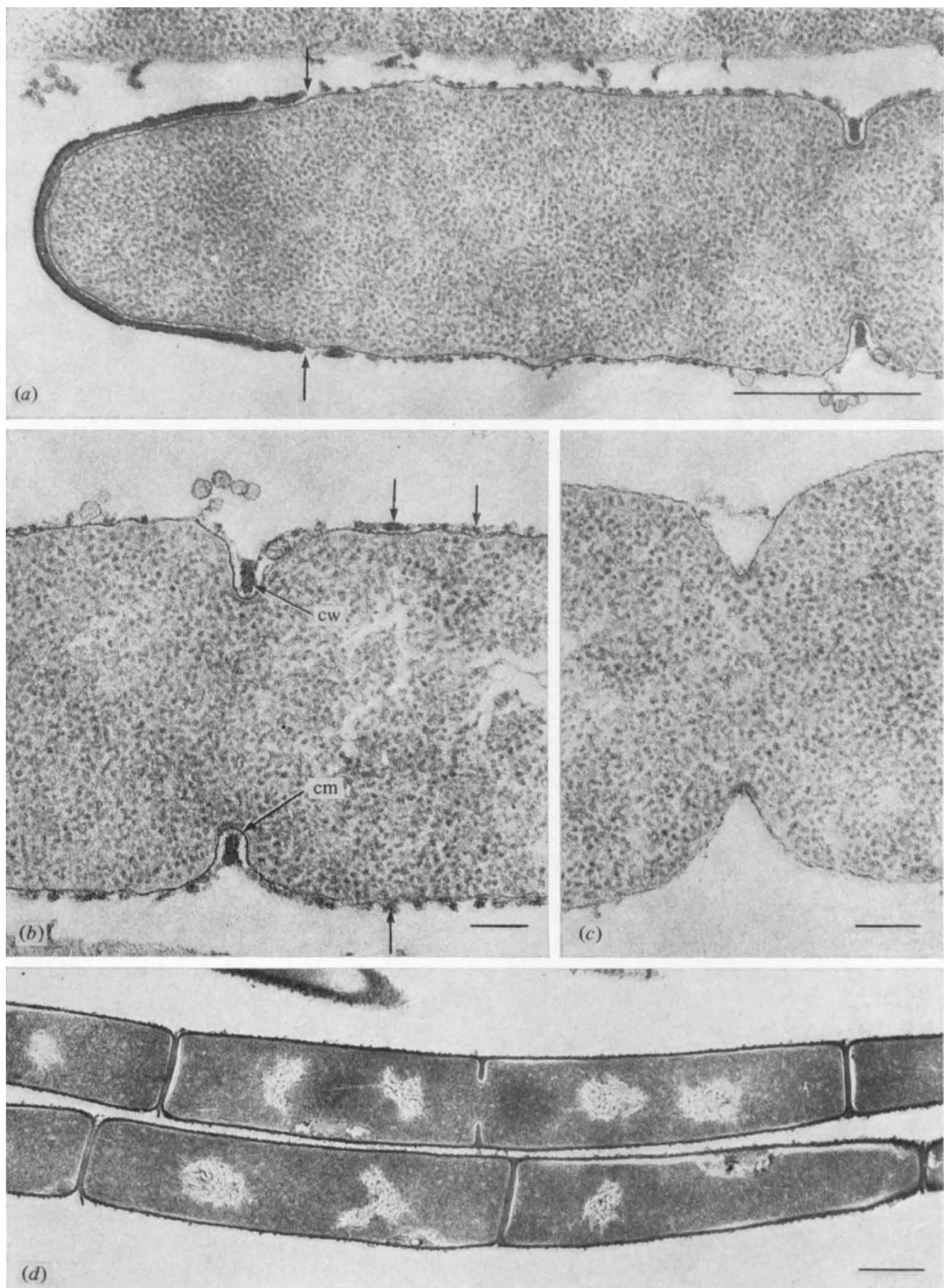

Fig. 10. Longitudinal sections of $B$. subtilis $168 / \mathrm{s}(a, b, c)$ and strain FJ6 $(d)$ grown in LB medium and prefixed with formaldehyde in $0.175 \mathrm{M}$-cacodylate buffer, $\mathrm{pH} \mathrm{6.2.} \mathrm{Arrows} \mathrm{in} a$ show intact wall at one distal pole; arrows in $b$ show fragments of wall material along the cylindrical portion of the cell, and there is partial (b) or extensive (c) degradation of the cross-wall $(\mathrm{cw}) ; \mathrm{cm}$, cytoplasmic membrane; the wall of strain FJ6 appears intact $(d)$. Bar markers represent $0.5 \mu \mathrm{m}(a, d)$ or $0.1 \mu \mathrm{m}(b, c)$. 
walls is likely to be about $27 \mathrm{~nm}$ in freeze-fractured, deep-etched material which has not been subject to dehydration and embedding. This value is very close to the mean $(26.9 \mathrm{~nm})$ determined from sections of strain 168/s. Preliminary measurements of freeze-fractured cells of $B$. subtilis $168 / \mathrm{s}$ indicate a mean value of $34 \cdot 7 \pm 6.4 \mathrm{~nm}$ (I. D. J. Burdett, unpublished observations) suggesting that sectioned wall profiles shrink by at least $23 \%$. The amount of wall shrinkage does not necessarily invalidate wall thickness determinations, however, because both in Streptococcus faecalis (Higgins et al., 1974) and B. subtilis (Hughes et al., 1970 ) thickness measurements parallel increases in wall polymer content during inhibition of protein synthesis. Measurements of relative wall thickness can therefore be made.

Alterations in thickness from loss of wall material, unless due to the removal of a very small fraction from the outer surface (Pooley, 1976), appear unlikely to account for the considerable reduction in thickness observed in strain FJ6. Fan et al. (1972a) have shown that the fringe of material can be removed from the outer surface of the wall in another autolytic-deficient strain of $B$. subtilis by the addition of autolysins or lysozyme. Thus, reductions in peripheral wall thickness in strain FJ6 might be due principally to modifications produced by fixation or alteration of wall properties.

Formaldehyde fixation, in a buffer of low ionic strength, appeared to result in a loss of wall material from the cross-wall and distal poles, perhaps reflecting the actual location of the autolysins. This result also suggests that the enzymes involved are relatively insensitive to formaldehyde; the addition of glutaraldehyde, a strong cross-linking agent, rapidly halts autolysis (Fig. 1). It is known, however, that formaldehyde can be readily washed out of fixed material (Hayat, 1970) and some of the effects observed in the present study could have occurred during subsequent stages of preparation, although wall damage seemed to be related to buffer concentration in a fairly direct manner. Under rather special conditions of autolysis in $0.3 \mathrm{M}-\mathrm{LiCl}$, favouring the activity of the amidase, Fan et al. (1972b) have shown that the cylindrical wall can be solubilized, leaving the ends and possibly the crosswalls apparently intact. Partial degradation of the cylindrical wall at increased buffer concentration was noted in strain 168/s (Fig. 10).

Wall degradation at the septum in the presence of formaldehyde indicates some interesting properties of the surface at this location. One possibility is that the nascent poles may be initially less cross-linked and only become fully cross-linked some time after cell separation. The implication is that formaldehyde, not itself a cross-linking agent, is incapable of stablilizing the most recently formed, and less cross-linked, wall. Polar wall appeared to be only partially degraded (Fig. $9 a, b$ ) because gradients of thickness were noted near sites of lysis even though the thickness of developing poles is relatively uniform (Burdett \& Higgins, 1978). Thus, the older portions of the pole, adjacent to the peripheral wall, are more resistant to lysis than the newly made surface. In B. megaterium (Fordham \& Gilvarg, 1974 ) and $S$. faecalis (Dezelee \& Shockman, 1975) the peptide cross-linking reaction has been shown to continue after incorporation of a suitable label. Secondly, modifications in the shape of distal poles, as well as possible changes in their resistance to autolysis, may occur by addition of wall material to the existing surface or by further cross-linking of the peptide chains in peptidoglycan. Shape modifications, involving an increase in wall thickness, have been observed in a Rod- mutant of B. subtilis (Burdett, 1979) where the ends of the cell appear to retain a distinct polarity of shape until well into the succeeding cycle of cross-wall construction. The poles are apparently as subject to turnover as the cylindrical wall (Fan et al., 1974).

Incubation of strain $168 / \mathrm{s}$ in TK or TM buffer did not lead to striking differences in the location of autolytic activity. Only in TM buffer was there evidence of a rather precise cutting of the cross-wall, whereas in TK buffer septal dissolution was much less specifically localized. In no case was the leading edge of the cross-wall the initial site of autolytic attack, as in $S$. faecalis (Higgins et al., 1970). The sequence of lysis in strain 168/s resembles that described for Lactobacillus acidophilus (Higgins et al., 1973) even though the sole 
known autolysin is a muramidase. At present it is difficult to relate the pattern of lysis in strain FJ6 to that in strain 168/s, because the initial event appears to involve the breakdown of the cytoplasmic membrane rather than the wall in the autolysin-deficient mutant. This may be due to, or consequent upon, the resistance of the walls to autolytic degradation.

I wish to thank Professor H. J. Rogers and Dr J. B. Ward for their helpful comments on the manuscript and Miss A. V. Greenslade and Mrs J. B. Whalley for excellent technical assistance.

\section{REFERENCES}

Beveridge, T. \& Murray, R. G. E. (1979). How thick is the Bacillus subtilis cell wall? Current Microbiology 2, 1-4.

Brown, W. C. \& Young, F. E. (1970). Dynamic interactions between cell wall polymers, extracellular proteases and autolytic enzymes. Biochemical and Biophysical Research Communications 38, 564-568.

BURDETT, I. D. J. (1979). Electron microscope study of the rod-to-coccus shape change in a temperature-sensitive Rod- mutant of Bacillus subtilis. Journal of Bacteriology 137, 1395-1405.

BurdetT, I. D. J. \& Higins, M. L. (1978). Study of pole assembly in Bacillus subtilis by computer reconstruction of septal growth zones seen in central, longitudinal thin sections of cells. Journal of Bacteriology 133, 959-971.

Burdett, I. D. J. \& Murray, R. G. E. (1974). Septum formation in Escherichia coli: characterisation of septal structure and the effects of antibiotics on cell division. Journal of Bacteriology 119, 303-324.

Chatterjee, A. N., Wong, W., Young, F. E. \& GILPIN, R. W. (1976). Isolation and characterisation of a mutant of Staphylococcus aureus deficient in autolytic activity. Journal of Bacteriology 125, 961-967.

Daneo-Moore, L. \& Shockman, G. D. (1977). The bacterial cell surface in growth and division. In Cell Surface Reviews, vol. 4, pp. 597-715. Edited by G. D. Poste \& G. Nicholson. Amsterdam: Elsevier-North Holland Publishing Co.

Dezflee, P. \& Shockman, G. D. (1975). Studies of the formation of peptide cross-links in the cell wall peptidoglycan of Streptococcus faecalis. Journal of Biological Chemistry 250, 6806-6816.

FAN, D. P. (1970). Autolysin(s) of Bacillus subtilis as dechaining enzyme. Journal of Bacteriology 103, 494-499.

Fan, D. P. \& Beckman, M. M. (1972). New centrifugation technique for isolating enzymes from large cell structures: isolation and characterisation of two Bacillus subtilis autolysins. Journal of Bacteriology 109, 1258-1265.

Fav, D. P., Beckman, M. M. \& Cunningham, W. P. (1972a). Ultrastructural studies on a mutant of Bacillus subtilis whose growth is inhibited due to insufficient autolysin production. Journal of Bacteriology 109, 1247-1257.

Fan, D. P., Pelvit, M. C. \& Cunningham, W. P. (1972b). Structural differences between walls from ends and sides of the rod-shaped bacterium Bacillus subtilis. Journal of Bacteriology 109, 1266-1272.
FAN, D. P., Beckman, B. E. \& BeckmaN, M. M. (1974). Cell wall turnover at the hemispherical caps of Bacillus subtilis. Journal of Bacteriology 117, $1330-1334$.

FEIN, J. E. (1979). Possible involvement of bacterial autolytic enzymes in fiagellar morphogenesis. Journal of Bacteriology 137, 933-946.

FeIN, J. E. \& Rogers, H. J. (1976). Autolytic enzyme-deficient mutants of Bacillus subtilis 168. Journal of Bacteriology 127, 1427-1442.

FORDHAM, W. D. \& GILvaRG, C. (1974). Kinetics of cross-linking of peptidoglycan in Bacillus megaterium. Journal of Biological Chemistry 249, 24782482.

Forsberg, C. W. \& Rogers, H. J. (1974). Characterisation of Bacillus licheniformis 6346 mutants which have altered lytic enzyme activities. Journal of Bacteriology 118, 358-368.

Glauert, A. M. (1975). Fixation, dehydration and embedding of biological specimens. In Practical Methods in Electron Microscopy, vol. 3, part I, p. 44. Edited by A.M. Glauert. Amsterdam: North-Holland Publishing Co.

HayAT, M. A. (1970). Principles and Techniques of Electron Microscopy: Biological Applications, vol. I, p. 86. Edited by M. A. Hayat. New York: Van Nostrand Reinhold Co.

Herbold, D. R. \& Glaser, L. (1975). Bacillus subtilis $N$-acetylmuramic acid L-alanine amidase. Journal of Biological Chemistry 250, 1676-1682.

Higgins, M. L. \& Shockman, G. D. (1976). Study of a cycle of cell wall assembly in Streptococcus faecalis by three-dimensional reconstructions of thin sections of cells. Journal of Bacteriology 127, 1346-1358.

Higgins, M. L., Pooley, H. M. \& Shockman, G. D. (1970). Site of initiation of cellular autolysis in Streptococcus faecalis as seen by electron microscopy. Journal of Bacteriology 103, 504-512.

Higgins, M. L., Coyette, J. \& Shockman, G. D. (1973). Sites of cellular autolysis in Lactobacillus acidophilus. Journal of Bacteriology 116, 13751382.

Higgins, M. L., Daneo-Moore, L., Boothby, D. \& Shockman, G. D. (1974). Effect of inhibition of deoxyribonucleic acid and protein synthesis on the direction of cell wall growth in Streptococcus faecalis. Journal of Bacteriology 118, 681-692.

HuGHES, R. C. (1970). Autolysis of isolated cell walls of Bacillus licheniformis NCTC 6346 and Bacillus subtilis Marburg strain 168. Preparation of the products and characterisation of the mucopeptide fragments. Biochemical Journal 119, 849-860.

Hughes, R. C., TANner, P. J. \& Stokes, E. (1970). 
Cell wall thickening in Bacillus subtilis. Biochemical Journal 120, 159-170.

MARQuis, R. E. (1968). Salt induced contraction of bacterial cell walls. Journal of Bacteriology 95, 775-781.

MulleR, J. H. (1972). Experiments in Molecular Genetics, p. 433. Cold Spring Harbor, N.Y.: Cold Spring Harbor Laboratory.

Piggot, P. J. \& TAYLOR, S. Y. (1977). New types of mutation affecting formation of alkaline phosphatase by Bacillus subtilis in sporulation conditions. Journal of General Microbiology 102, 69-80.

PoOley, H. M. (1976). Layered distribution, according to age, within the cell wall of Bacillus subtilis. Journal of Bacteriology 125, 1139-1147.

ROGERS, H. J. (1967). Killing of staphylococci by penicillins. Nature, London 213, 31-33.

Rogers, H. J. (1970). Bacterial growth and the cell envelope. Bacteriological Reviews 34, 194-214.

Rogers, H. J. (1979). The function of bacterial autolysins. In Microbial Polysaccharides and Polysaccharases, pp. 237-268. Edited by R.C.W. Berkeley, G. W. Gooday \& D. C. Ellwood. London: Academic Press.

Rogers, H. J. \& Forsberg, C. W. (1971). Role of autolysins in the killing of bacteria by some bac- tericidal antibiotics. Journal of Bacteriology 108, 1235-1243.

SARGent, M. G. (1973). Control of cell length in Bacillus subtilis. Journal of Bacteriology 123, 7-19.

Shockman, G. D. \& Martin, J. T. (1968). Autolytic enzyme system of Streptococcus faecalis. IV. Electron microscopic observations on autolysin and lysozyme action. Journal of Bacteriology 96, 1803-1810.

SPURR, A. R. (1968). A low viscosity epoxy resin embedding medium for electron microscopy. Journal of Ultrastructure Research 26, 31-43.

Tomasz, A. (1968). Biological consequences of the replacement of choline by ethanolamine in the cell wall of pneumococcus: chain formation, loss of transformability, and loss of autolysis. Proceedings of the National Academy of Sciences of the United States of America 59, 86-93.

Westmacott, D. \& Perkins, H. R. (1979). Effects of lysozyme on Bacillus cereus 569: rupture of chains of bacteria and enhancement of sensitivity to autolysins. Journal of General Microbiology 115, 1-11.

YouNG, F. E. (1966). Autolytic enzyme associated with cell walls of Bacillus subtilis. Journal of Biological Chemistry 241, 3462-3467. 